Short Paper

\title{
Rapid Dives and Ascents of Sockeye Salmon Oncorhynchus nerka Observed by Ultrasonic Telemetry in the Open Sea
}

\author{
Miki Ogura \\ National Research Institute of Far Seas Fisheries, Orido, Shimizu, Shizuoka 424-8633, Japan \\ (Received September 28, 1998)
}

Key words: diving behavior, sockeye salmon, salmon, biotelemetry, Bering Sea

Horizontal and vertical movements of fish in the open ocean can be determined using ultrasonic depth sensitive transmitters. Many tracking studies conducted previously in coastal waters have provided data on the vertical distributions and movements of salmonids in relation to environmental factors, as well as their homing abilities. ${ }^{1-3)}$ The accuracy of the vertical movement information depends mainly on the pressure sensor performance in a transmitter and, at present, is much higher than that of the horizontal movement which is considerably effected by position finding errors. ${ }^{4)}$ Rates of vertical movement were one of the types of information easily calculated in these studies, and adult salmonids at sea were considered to move vertically at a relatively slow rate ranging from 0.05 to $0.33 \mathrm{~m} / \mathrm{s}$. But, here I describe the first record of 4 rapid dives and ascents observed during the tracking of sockeye salmon Oncorhynchus nerka in the open sea.

Tracking studies of sockeye salmon using ultrasonic telemetry were conducted in the international waters of the central Bering Sea in June and July, 1990 and 1991. Four fish used were caught by surface longline and ranged in fork length from 582 to $648 \mathrm{~mm}$. All of them were ocean age 3. A cylindrical depth-sensing transmitter (length 65 $\mathrm{mm}$, diameter $15 \mathrm{~mm}$, underwater weight $11 \mathrm{~g}$; VEMCO Ltd., Dartmouth, Nova Scotia, Canada) was attached externally, immediately anterior to the dorsal fin of the fish. The tracking system and equipment used were same as described in Ogura and Ishida. ${ }^{\text {s }}$ Swimming depth data were recorded at approximately 5 second intervals during the track. The rate of vertical movement (vertical movement distance per second) were calculated for dives or ascents of more than $10 \mathrm{~m}$.

A total of 216 hours of vertical movement data for 4 sockeye salmon were available. Each of the 4 fish made initial dives to $25-49 \mathrm{~m}$ as an escape behavior immediately following release. They stayed these depths for a short time and ascended slowly to the surface. After that sockeye remained mainly upper $10 \mathrm{~m}$ but occasionally made short vertical excursions. In most excursions, sockeye started to ascend immediately following the dive, resulting in a Vshaped vertical movement pattern in the time-depth diagram. The typical behavior of fish tracked was shown in Ogura and Ishida ${ }^{6}$ and detailed vertical movements of each fish were shown in Ogura. ${ }^{* 1, * 2}$

108 dives and 95 ascents of more than $10 \mathrm{~m}$ were observed. Average rates of vertical movements were 0.19 (range $0.06-2.19) \mathrm{m} / \mathrm{s}$ and $0.16(0.00-0.83) \mathrm{m} / \mathrm{s}$ during dives and ascents, respectively. Rates of vertical movements of $95 \%$ of dives and ascents were under $0.5 \mathrm{~m} / \mathrm{s}$ (Fig. 1). The rates of vertical movement of initial dives were $0.12-0.43 \mathrm{~m} / \mathrm{s}$.

Three of the 4 fish tracked showed unusual deep and fast vertical movements; (i) The sockeye (\#1) descended in the afternoon of the fourth day of tracking from $6 \mathrm{~m}$ to $150 \mathrm{~m}$ in $66 \mathrm{~s}(2.19 \mathrm{~m} / \mathrm{s})$ and then ascended slowly $(0.16$ $\mathrm{m} / \mathrm{s}$ ) to $5 \mathrm{~m}$. Eight and a half hours after this rapid vertical excursion, the tracking was terminated because the transmitter may become separated from the fish or the fish may die. (ii) The sockeye (\#2) dived at the afternoon of the second day of tracking from $4 \mathrm{~m}$ to $49 \mathrm{~m}$ in $30 \mathrm{~s}(1.50 \mathrm{~m} / \mathrm{s})$ and then dived to about $80 \mathrm{~m}$ at a slower rate $(0.15 \mathrm{~m} / \mathrm{s})$. Immediately following this dive, fish ascended at $0.83 \mathrm{~m} / \mathrm{s}$ to $10 \mathrm{~m}$ and then at a slower rate $(0.03 \mathrm{~m} / \mathrm{s})$ to near surface. (iii) At nighttime, two and a half hours after the previous rapid vertical excursion, the same fish $(\# 2)$ dived from $31 \mathrm{~m}$ to $174 \mathrm{~m}$ at $0.43 \mathrm{~m} / \mathrm{s}$, and then continued down to $220 \mathrm{~m}$ at a slower rate $(0.16 \mathrm{~m} / \mathrm{s})$. During the subsequent 2 hours, this fish swam between 207 and $244 \mathrm{~m}$. The fish then ascended to $170 \mathrm{~m}$ at $0.16 \mathrm{~m} / \mathrm{s}$, and ascended to $11 \mathrm{~m}$ at $0.63 \mathrm{~m} / \mathrm{s}$; between 144 and $70 \mathrm{~m}$ ascended at 1.14 $\mathrm{m} / \mathrm{s}$. Sixteen hours after this second ascension, the fish (\#2) was lost. (iv) The sockeye (\#3) dived at the afternoon of the first day of tracking, 8 hours after release, from the surface to $65 \mathrm{~m}$ in $105 \mathrm{~s}(0.62 \mathrm{~m} / \mathrm{s})$; between 8 and $52 \mathrm{~m}$ the rate of descent was $1.41 \mathrm{~m} / \mathrm{s}$. After about one minute at $52 \mathrm{~m}$, the fish ascended slowly $(0.15 \mathrm{~m} / \mathrm{s})$. The tracking of this fish (\#3) was continued two days after this vertical excursion and lost.

Rates of vertical movement of some part of four rapid dives and ascents ( $\mathrm{i}-\mathrm{iv}$ ) exceeded the range of usual vertical movements previously known. Also at these dives fish reached deeper layers than the usual swimming layer (less than $50 \mathrm{~m}$ ). Rates of vertical movement of vertical excursions of adult salmonids in the coastal waters were reported to be $0.05-0.20 \mathrm{~m} / \mathrm{s}$ for chum Oncorhynchus keta, ${ }^{3,7-10)}$ and $0.08-0.33 \mathrm{~m} / \mathrm{s}$ for sockeye. ${ }^{1)}$ In the open sea, the rates

\footnotetext{
${ }^{*}$ M. Ogura: Outline of biotelemetry study of salmon by Shin-Riasu maru, 1990. Document submitted to the International North Pacific Fisheries Commission. Fisheries Agency of Japan, National Rsearch Institute of Far Seas Fisheries, Orido, Shimizu, Japan. 19p. (1990).

${ }^{*}$ M. Ogura: Outline of biotelemetry study of salmon by Shin-Riasu maru, 1991. Document submitted to the International North Pacific Fisheries Commission. Fisheries Agency of Japan, National Research Institute of Far Seas Fisheries, Orido, Shimizu, Japan. 26p. (1991).
} 


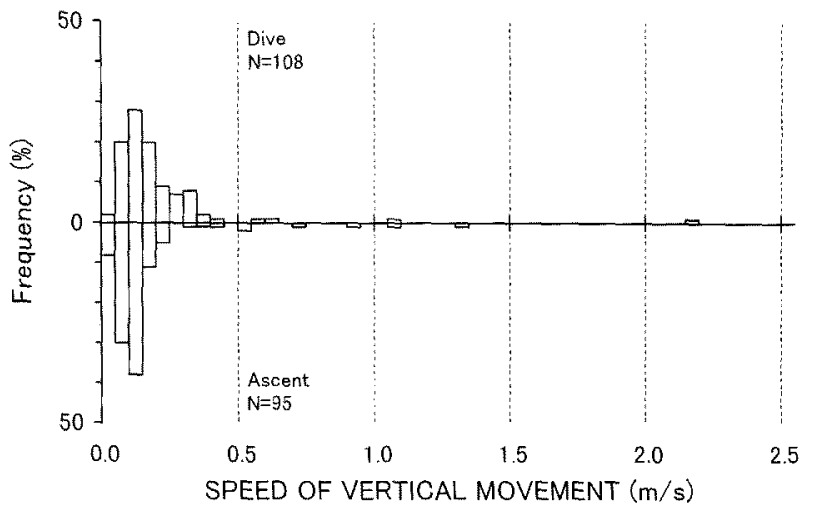

Fig. 1. Frequency distributions of rates of vertical movement of dives and ascents of more than $10 \mathrm{~m}$ for combined data of 4 sockeye salmon.

of vertical movement of coho salmon Oncorhynchus kisutch were $0.08 \mathrm{~m} / \mathrm{s} .^{5)}$ Although rates of initial dives of coho and chum were more rapid than those of usual dives, ${ }^{5,11)}$ rates of initial dives of sockeye salmon in this study were less than $0.43 \mathrm{~m} / \mathrm{s}$ and were within the range of the rate of usual vertical excursion.

Sockeye were exposed to relatively steep temperature gradients during rapid dives and ascents. There was a narrow water temperature range of $2^{\circ} \mathrm{C}$ in which they swam during two or three days of tracking, because their movements were restricted mostly to the mixed layer. In the case of the rapid dive of (i), however, it experienced a $5.1^{\circ} \mathrm{C}$ change in water temperature in $66 \mathrm{~s}$. Since salmonids are plysostomic fish, the sockeye tracked appeared to be neutrally buoyant near surface and after a rapid dive sockeye were negatively buoyant. Therefore fish may have to ascend quickly to their previous depth after dive in order to reduce energy consumption. ${ }^{12)}$ But in the dive of (iii), sockeye stayed in the deep layer during fairly long time, this indicates that there may be an unknown advantage of swimming in the deeper layer for the fish.

It is clear that rapid dives made uncommon changes of environments for sockeye salmon and these were energetically ineffective. The motivation of vertical movement is attributed in the feeding, escape from predator, environmental change, and especially in the coastal waters, search for their natal river system, but the exact motivation for these rapid dives presented here is not clear. They appear to feed mainly euphausiids, hyperiid amphipods, and small fish and squid, ${ }^{13)}$ so no rapid vertical movements were expected to be necessary. Although the fish may have encountered marine mammals or other predators, there were no marine mammals observed around the tracking vessel before and during these dives. Seabirds were observed around the tracking vessel during these dives and the transmitter was an intense orange color, so in the case of dive (iv) from the surface, it was possible that the fish was attacked by seabirds while swimming at the surface. From the data of the surface water temperature and water temperature profiles by $8 \mathrm{~h}$ intervals of expendable bathythermograph observations, there was no dramatic change of environment.

For salmonids, rapid dives and ascents have been observed in only trackings of sockeye so far. For other species, one bigeye tuna Thunnus obesus showed a rapid dive of $230 \mathrm{~m}$ in 1 minute. ${ }^{14)}$ Although rapid dives and ascents seemed to be a rare behavior for salmonids, our observations show that adult sockeye have the ability to move vertically up to $2.19 \mathrm{~m} / \mathrm{s}$ (equivalent to 3.76 fork length $/ \mathrm{s}$ ) against the great gradients of pressure and temperature.

I am grateful to Captain Yoshinobu Muraki and his officers and crew of the R/V Shin-Riasu maru for their kind assistance during the survey. I also express my thank to Dr. Richard Brill, Southeast Fisheries Science Centre, Honolulu, for reviewing the manuscript.

\section{References}

1) T. P. Quinn, B. A. TerHart, and C. Groot: Behav., 37, 587-599 (1989).

2) G. T. Ruggerone, T. P. Quinn, I. A. Mcgregor, and T. D. Wilkinson: Can. J. Fish. Aquat. Sci., 47, 1963-1969 (1990).

3) K. Yano and A. Nakamura: J. Ichthyol., 39, 67-83 (1992).

4) A. D. Hawkins and G. G. Urquhart: in "Experimental Biology at Sea" (ed. by A. G. Macdonald and I. G. Prieda), Academic Press, London, 1983, pp. 103-166.

5) M. Ogura and Y. Ishida: Can. J. Fish. Aquat. Sci, 49, 453-457 (1992).

6) M. Ogura and Y. Ishida: Can. J. Fish. Aquat. Sci., 52, 532-540 (1995).

7) T. Ichihara, T. Yonemori, and H. Asai: Bull. Far Seas Fish. Lab., 13, 63-77 (1975).

8) T. Ichihara and A. Nakamura: in "Proceeding of North Pacific Aquaculture Symposium, Anchorage, Alaska, August 18-21, $1980^{\prime \prime}$ (ed. by B. R. Melteff and R. A. Neve), University of Alaska, 1982, pp. 39-49.

9) H. Soeda, K. Yoza, T. Shimamura, E. Hasegawa, and K. Yoshihara: Nippon Suisan Gakkaishi, 51, 1425-1429 (1985).

10) T. Shimamura, K. Yoza, E. Hasegawa, and M. Furuta: Nippon Suisan Gakkaishi, 53, 411-415 (1987).

11) H. Soeda, K. Yoza, and T. Shimamura: Nippon Suisan Gakkaishi, 53, 1827-1833 (1987).

12) G. P. Arnold and M. G. Walker: ICES J. Mar. Sci., 49, 357-372 (1992).

13) W. Percy, T. Nishiyama, T. Fujii, and K. Masuda: Fish. Bull., 82 , 391-399 (1984)

14) K. N. Holland, R. W. Brill, and R. K. C. Chang: Fish. Bull., 88, 493-507 (1990). 